\title{
Task Specific Lingual Dystonia: An Uncommon Cause of Isolated Dysarthria
}

\author{
Miseon Kwon ${ }^{\mathrm{a}}$, Hae-Won Shin ${ }^{\mathrm{b}}$, Jong S. Kim ${ }^{\mathrm{a}}$ \\ ${ }^{a}$ Department of Neurology, Asan Medical Center, University of Ulsan College of Medicine, Seoul, Korea \\ ${ }^{b}$ Department of Neurology, Chung-Ang University Hospital, Chung-Ang University College of Medicine, Seoul, Korea
}

\author{
Correspondence: Miseon Kwon, PhD, CCC-SLP \\ Department of Neurology, Asan Medical Center, \\ University of Ulsan College of Medicine, 88 \\ Olympic-ro 43-gil, Songpa-gu, Seoul 138-736, \\ Korea \\ Tel: +82-2-3010-3984 \\ Fax: +82-2-474-4691 \\ E-mail: mskwon@amc.seoul.kr
}

Received: April 8, 2013

Revised: May 19, 2013

Accepted: May 25, 2013

This research was supported by a grant by Basic Science Research Program through the National Research Foundation of Korea (NRF) funded by the Ministry of Education, Science and Technology (No. 2010-0024353).
Objectives: Dysarthria is a common neurologic symptom and is produced by a variety of neurologic disorders. Hyperkinetic type of dysarthria is indicated as a plural disorder because it includes many heterogeneous involuntary movements including dystonia. Isolated dysarthria due to lingual dystonia is rarely encountered. We describe a patient presenting with isolated dysarthria caused by lingual dystonia. Case: A 50-year-old man visited our hospital due to dysarthria. His medical and psychological history was not remarkable. The results of neurological examinations did not reveal any motor or sensory abnormalities. However, on speech examination, he demonstrated dystonic movements of the tongue aggravated on speaking and during rest with mouth opening. The dystonic movements disappeared when he protruded his tongue and did not occur during chewing or eating behaviors. After exclusion of other causes of tongue dystonia, he was diagnosed as having primary lingual dystonia. Conclusion: We presented a patient with isolated dysarthria caused by dystonia specifically involving the tongue. Our case illustrates that task specific lingual dystonia should be considered as one of the causes of isolated speech disturbances.

Keywords: Hyperkinetic dysarthria, Dystonia, Tongue, Task-specific
Dysarthria is a motor speech disorders that is caused by various neurological diseases including peripheral neuropathy, neuromuscular junction disorders, and pyramidal and extrapyramidal central nervous system lesions. It can be classified into different types of dysarthria depending on the characteristics of neurologic and speech disturbance, such as flaccid, spastic, ataxic, hypokinetic, hyperkinetic, unilateral upper motor neuron, and mixed type (Duffy, 2005).

Hyperkinetic dysarthrias are often associated with diseases of the basal ganglia control circuit and concurrently show involuntary movements that interfere with normal speech productions. This type of dysarthria is indicated as a plural disorder because it includes many heterogeneous involuntary movements (Duffy, 2005). Huntington disease is a degenerative disorder which is most commonly associated with hyperkinetic dysarthrias. However, other involuntary movements such as myoclonus, dystonia, spasm, and tremor also can affect speech production and demonstrate different characteristics of speech disturbances depending on involved movements.

Dystonia is slow and sustained involuntary movements characterized by abnormal postures. However, dystonia may involve only oral/facial muscles and cause specific speech disturbances. Lingual dystonia is commonly presented as a form of neuroleptic-induced tardive dystonia (Tan \& Jankovic, 2000). In addition, it is occasionally reported in patients with brainstem (Lee \& Yeo, 2005) or thalamic infarction (Kim et al., 2009), or as a post-traumatic movement disorder (Ondo, 1997). However, isolated primary lingual dystonia has rarely been described. So far, limited numbers of cases with primary focal lingual dystonia have been reported (Baik, Park, \& Kim, 2004; Degirmenci, Ors, Yilmaz, \& Karaman, 2011; 
Ishii, Takaoka, \& Shoji, 2001; Ozen, Gunal, Turkmen, Agan, \& Elmaci, 2011; Papapetropoulos \& Singer, 2006; Tan \& Chan, 2005). Herein, we describe a patient with dysarthria caused by lingual dystonia. Interestingly, the dystonic movements were aggravated on speaking and preferentially appeared during rest with mouth opening but subsided with protrusion of the tongue.

\section{CASE REPORT}

A 50-year-old man was admitted to our hospital due to a subacute onset of dysarthria that had developed two weeks earlier. He complained that his tongue was curled during speaking, but he had no discomfort while chewing or swallowing. His medical history was unremarkable, and he denied of using any antidopaminergic drugs, including gastrointestinal prokinetics and neuroleptics.

Neurological examination showed that there was no definitive weakness in the tongue, masseter, and facial muscles. Tough, pinprick, cold temperatures and vibration sensations were normally perceived in the face and tongue. On speech examination, he showed inconsistent articulatory breakdowns throughout the speech with alternative $(/ \mathrm{t} \Lambda /, / \mathrm{k} \Lambda /)$ and sequential $(/ \mathrm{p} \Lambda \mathrm{t} \Lambda \mathrm{k} \Lambda /)$ motions of the tongue. However, articulatory abnormalities were not observed on producing bilabial sounds, such as $/ \mathrm{p} \Lambda /$. On his conversational speech and reading, irregular changes of stress and rates of speech were also observed. The symptoms were aggravated by keeping him speaking.

Further examinations of oral motor functions revealed intermittent contractions of his tongue muscles occasionally inducing involuntary movements during mouth openings. These movements were involuntary and could not be controlled by his will. The involuntary tongue contractions did not bother him from chewing or eating, and were not observed while he swallowed test materials, which was confirmed by video fluoroscopy. However, the abnormal tongue movements disappeared while he protruded his tongue. There were no involuntary movements in other body parts, including his jaw and mouth. Electromyographic study in the bilateral genioglossus muscles did not show any abnormal discharges on rest.

Other neurological examinations showed normal results, as were the results of routine hematologic, biochemical, and thyroid function tests and tests for Wilson disease. Brain magnetic resonance imaging showed no abnormal findings. After exclusion of secondary causes of tongue dystonia, he was diagnosed as having primary lingual dystonia. Initial treatment with $1.5 \mathrm{mg}$ of clonazepam for one month failed to improve his symptoms, but a change to $6 \mathrm{mg}$ of trihexyphenidyl resulted in moderate improvements. Two months after starting trihexyphenidyl treatment, his involuntary tongue movements were no longer observed while resting. However, mild dysarthria was occasionally presented during connected speech.

\section{DISCUSSION}

The patient presented with isolated dysarthria that was caused by dystonia specifically involving the tongue. Although the most common form of lingual dystonia is the neuroleptic-induced tardive dystonia (Tan \& Jankovic, 2000), it can be found in patients with cerebral infarction (Kim et al., 2009; Lee \& Yeo, 2005) or recognized as a post-traumatic movement disorder (Ondo, 1997). Patients with isolated primary lingual dystonia are rare. (Baik et al., 2004; Degirmenci et al., 2011; Ishii, Takaoka, \& Shoji, 2001; Ozen et. al, 2011; Papapetropoulos \& Singer, 2006; Tan \& Chan, 2005). The dystonic contractions of the tongue were protrusions with or without lateral displacement and it was always induced by speaking (Table 1). In contrast to neuroleptic-induced tardive dyskinesia, these patients are relatively young, and do not show involuntary movements in other facial muscles such as the jaw, mouth and eyes. Moreover, their symptoms were generally responsive to anticholinergic medications as in our patient even though recent study reported that botulinum toxin injections could be an effective way to release such symptoms.

Interestingly, our patient's lingual dystonia that was aggravated during mouth opening was subsided when he protruded his tongue. This observation appears to be contrary to dystonic movements of the tongue described in previous reports, which included protrusional tongue movements (Table 1). Thus, idiopathic tongue dystonia may not be a homogenous disorder. During tongue protrusion, the activation of genioglossus muscle plays a central role ( $\mathrm{Pa}-$ papetropoulos \& Singer, 2006) while the activity of extrinsic muscles is relatively reduced in resting position. The activity of extrin- 
Table 1. Summary of previously reported cases with primary focal tongue dystonia

\begin{tabular}{|c|c|c|c|}
\hline Case & Sex/age & Dystonic movements of the tongue & Treatment \\
\hline Ishii, Tamaoka, \& Shoji (2001) & $\mathrm{M} / 32$ & "repeatedly protrude forward" & Trihexyphenidyl (8 mg/day for 5 month) \\
\hline Baik, Park, \& Kim (2004) & $\mathrm{F} / 46$ & "protruded and was uncontrolled" & Trihexyphenidyl (4 mg/day for 4 month) \\
\hline Tan \& Chan (2005) & $\mathrm{F} / 50$ & "curl up and occasionally pulled up to one side of the mouth" & Tetrabenazine, benzodiazepines and sensory tricks \\
\hline Papapetropoulos \& Singer (2006) & $M / 39$ & "curled" & Trihexyphenidyl (10 mg/day) \\
\hline Degirmenci, Ors, Yilmaz, \& Karaman (2011) & $\mathrm{F} / 42$ & "uncontrolled protrusion" & Botulinum toxin injection \\
\hline Ozen, Gunal, Turkmen, Agan, \& Elmaci (2011) & $M / 55$ & "curled and protruded" & Botulinum toxin injection \\
\hline
\end{tabular}

sic muscles of the tongue is relatively reduced in resting position or during speech. According to animal studies (Altschuler, Bao, \& Miselis, 1994; Dobbins \& Feldman, 1995; Guo, Goldberg, \& McClung, 1996; McClung \& Goldberg, 1999; Pittman \& Bailey, 2009; Sokoloff, \& Deacon, 1992), tongue protrusion is controlled by the motor neurons in the ventral part of the nucleus, whereas retrusion is regulated by those in the lateral and dorsolateral part. The remainder of the nucleus controls intrinsic muscles of the tongue. Previous studies reported that central pattern generators of one movement suppressed those of the other during respiration and swallowing (McFarland \& Lund, 1995; Sawczuk \& Mosier, 2001), similar processes may functionally operate in intrinsic or extrinsic muscles of the tongue. Therefore, it may be assumed that lingual dystonia of our patient mainly involves the intrinsic muscles of the tongue and subsides during the interaction of the extrinsic muscles.

In addition, our patient's lingual dystonia was induced or aggravated by speaking but not by chewing or swallowing. Indeed, we observed that involuntary tongue contractions aggravated on reading while they disappeared during oral-pharyngeal phases of swallowing on videofluoroscopy. The pattern generator in the brainstem for the tongue movement is controlled by the cortical projection. According to an intracortical microstimulation experiment using monkeys, the firing rates of electrodes recording neuronal activities in the tongue-representing cortical area are differentially modulated depending on the tasks of tongue protrusion or swallowing (Martin, Murray, Kemppainen, Masuda, \& Sessle, 1997). Thus, the cortical patterns of controlling oral motor activities may also be different between speech and non-speech tongue activities (Bunton, 2008). Our patient showed clinical evidence of posture/task specific lingual dystonia and provides further evidence supporting for these experimental data.

In summary, our patient showed that primary lingual dystonia aggravated by speaking should be considered as one of the causes of isolated speech disturbances. Suspecting this diagnosis would be of practical importance because anticholinergics may be efficacious in these patients.

\section{REFERENCES}

Altschuler, S. M., Bao, X., \& Miselis, R. R. (1994). Dendritic architecture of hypoglossal motorneurons projecting to extrinsic tongue musculature in the rat. Journal of Comparative Neurology, 342, 538-550.

Baik, J. S., Park, J. H., \& Kim, J. Y. (2004). Primary lingual dystonia induced by speaking. Movement Disorders, 19, 1251-1252.

Bunton, K. (2008). Speech versus nonspeech: different task, different neural organization. Seminars in Speech and Language, 29, 267-275.

Degirmenci, Y., Ors, C. H., Yilmaz, Y., \& Karaman, H. I. (2011). Isolated lingual dystonia induced by speaking: a rare form of focal dystonia. Acta Neurologica Belgica, 111, 360-361.

Dobbins, E. G., \& Feldman, J. L. (1995). Differential innervation of protruder and retractor muscles of the tongue in rat. Journal of Comparative Neurology, 357, 376-394.

Duffy, J. R. (2005). Motor speech disorders: Substrates, differential diagnosis, and management. St. Louis, MO: Elsevier.

Guo, Y., Goldberg, S. J., \& McClung, J. R. (1996). Compartmental organization of stylogossus and hypoglossus motoneurons in the hypoglossal nucleus of the rat. Brain Research, 728, 277-280.

Ishii, K., Tamaoka, A., \& Shoji, S. (2001). A case of primary focal lingual dystonia induced by speaking. European Journal of Neurology, 8, 507.

Kim, H. J., Lee, M. C., Kim, J. S., Chung, S. J., Kwon, M., \& Shin, H. W. (2009). Lingual dystonia as a manifestation of thalamic infarction. Movement Disorders, 24, 1703-1704.

Lee, P. H., \& Yeo, S. H. (2005). Isolated continuous rhythmic involuntary tongue movements following a pontine infarct. Parkinsonism and Related Dis- 
orders, $11,513-516$

Martin, R. E., Murray, G. M., Kemppainen, P., Masuda, Y., \& Sessle, B. J. (1997) Functional properties of neurons in the primate tongue primary motor cortex during swallowing. Journal of Neurophysiology, 78, 1516-1530.

McClung, J. R., \& Goldberg, S. J. (1999). Organization of motoneurons in the dorsal hypoglossal nucleus that innervate the retrusor muscles of the tongue in the rat. Anatomical Record, 254, 222-230.

McFarland, D. H., \& Lund, J. P. (1995). Modification of mastication and respiration during swallowing in the adult human. Journal of Neurophysiology, 74, 1509-1517.

Ondo, W. (1997). Lingual dystonia following electrical injury. Movement Disorders, $12,253$.

Ozen, B., Gunal, D. I., Turkmen, C., Agan, K., \& Elmaci, N. T. (2011). Speechinduced primary lingual dystonia: a rare focal dystonia. Neurological Sciences, 32, 155-157.

Papapetropoulos, S., \& Singer, C. (2006). Primary focal lingual dystonia. Move- ment Disorders, 21, 429-430.

Pittman, L. J., \& Bailey, E. F. (2009). Genioglossus and intrinsic electromyographic activities in impeded and unimpeded protrusion tasks. Journal of Neurophysiology, 101, 276-282.

Sawczuk, A., \& Mosier, K. M. (2001). Neural control of tongue movement with respect to respiration and swallowing. Critical Reviews in Oral Biology \& Medicine, 12, 18-37.

Sokoloff, A. J., \& Deacon, T. W. (1992). Musculotopic organization of the hypoglossal nucleus in the cynomolgus monkey, Macaca fascicularis. Journal of Comparative Neurology, 324, 81-93.

Tan, E. K., \& Chan, L. L. (2005). Sensory tricks and treatment in primary lingual dystonia. Movement Disorders, 20, 388.

Tan, E. K., \& Jankovic, J. (2000). Tardive and idiopathic oromandibular dystonia: a clinical comparison. Journal of Neurology, Neurosurgery, and Psychiatry, 68, 186-190. 


\section{국문초록}

\section{과제특정적 혀 근긴장이상증으로 인한 마비말장애}

\section{권미선 - 신혜원 ${ }^{2}$ 김종성 1}

'울산대학교의과대학, 서울아산병원신경과, ${ }^{2}$ 중앙대학교의과대학 중앙대학교병원신경과

배경 및 목적: 마비말장애는 다양한 신경학적 질환들로 인해 초래되며 그 특성에 따라 여러 유형으로 분류된다. 과다운동형 마비말장 애는 기저를 이루는 불수의적 움직임이 매우 다양하기 때문에 보통 복수형으로 표시하며 그 중에서도 근긴장이상증은, 특히 말산출과 같은 특정과제에서만 나타나는 국소적 혀의 근긴장이상증은, 과다운동형 마비말장애를 일으키는 매우 드문 원인으로 알려져 있다. 사 례: 55세 남자 환자가 말을 할 때 혀가 꼬인다는 것을 주소로 병원에 내원하였다. 고혈압이나 기타 의학적 심리학적 질환에 대한 기왕력 은 전혀 없었다. 신경학적 검사에서 감각이나 운동이상도 없었으며 뇌 자기공명 영상검사나 근전도검사 등 다른 검사상에서도 이상소 견은 보이지 않았다. 그러나 언어평가 결과, 말산출 시와 구강기능평가 시에 입을 벌리고 있는 과제에서 혀의 근긴장이상 증상이 관찰되 었고 이러한 증상은 다른 구강기능 평가과제 시나 씹기, 삼키기와 같은 말산출 이외의 활동 중에는 나타나지 않았다. 논의 및 결론: 말 산출과 같은 특정과제에서 혀에 단독적으로 나타나는 근긴장이상증은 드문 장애로마비말장애를 일으키는 원인이 될 수 있다. 마비말 장애 이외의 다른 증상이 동반되지 않는 환자의 경우 혀 근긴장이상증의 가능성도 고려해 보아야 할 것이다.

핵심어: 과다운동형 마비말장애, 근긴장이상증, 혀, 과제특정적

이 논문은 2010년도 정부(교육과학기술부)의 재원으로 한국연구재단의 지원을 받아 수행된 기초연구사업임(No. 2010-0024353). 